\title{
FOREIGN CAPITAL INFLOWS AND ECONOMIC GROWTH IN SAARC
}

\author{
Muhammad Abdullah Idrees \\ Faculty of Management Sciences, Indus University \\ Email-mabdullahidress@indus.edu.pk
}

\begin{abstract}
The purpose of the study is to find out the impact of foreign debt, foreign portfolio investment, foreign direct investment, foreign remittance and foreign import on economic development. For this purpose, we use data from 1992 to 2015 from World Bank sites of the selected SAARC countries namely Pakistan, India, Bangladesh, and Sri Lanka. An Econometric view tool is applied to find out impact of independent and dependent variable. For this Panel Unit Root test, Panel co-integration test, panel regression model (Fixed or random effect) and granger causality is used. The findings of panel unit root test are showing that the variables are not stationary at level but at first level all variables are stationary. Panel co-integration test shows the long relationship among variables. Foreign Imports, Foreign direct investment and foreign remittance have positive impact on GDP, whereas foreign portfolio investment and foreign debt have negative impact on GDP. Lastly Granger causality shows that FDI, $F D$ and FI have unidirectional relation but FR and FPI doesn't have any relation.
\end{abstract}

Keywords: gross domestic product, foreign direct investment, foreign debt, foreign portfolio investment foreign imports, foreign remittance \& SAARC.

\section{Introduction}

\subsection{Background}

In this challenging world, the developed nations remain focused toward keep monetary development in long run (Shah, Khan \& Tahir, 2015). Monetary development cannot be defined easily except through its numerous features as it is of difficult natural surroundings. These factors are interior and exterior both. Assets and social wealth lie below inner or helps feature which are significant aimed at achieving the great monetary development, while foreign direct investment, foreign remittances, 
foreign portfolio investment, foreign debts and foreign imports arises below exterior features of economic growth they all similarly play a dynamic part for developed high economic growth.

Foreign Portfolio Investment (FPI) is dignified by the asset through via imported thing in single nation in the group of fairness plus debit safeties of an initiative to a different nation (Mucuk, Demirsel \& Sahin, 2014). These funds can be completed as in bonds, cash marketplace, notes to economic products. FPI complete the situation excessive effect happening the monetary development as it is used well and successfully in industrious fields. Through, FPI is also probable to showcase economic variability. This one might affect in declining the further reserves and make FPI to short term foreign funds which can be costly and brings the economic crisis.

Over the last few years, Foreign Direct Assets must be one of the most important parts of the global economy. With the growth of the economy, it is measured as a mechanism because these movements of advanced countries have been developed with a large margin (Herzer, 2010). Due to recent market price changes, positive investment strategies and job liberalization, the FDI also made its impact on SAARC countries, such as more developed countries. Benefits of FDI can also be achieved through a changed approach. First, the FDI supports even giving a fund to meet the property. Secondly, this is often the global carrier's global network. Finally, the FDI has created countries that have shown that the country's low rate is growing and decreasing (Bhattarai, 2016).

The most widespread financial development is the actual money transfer, but is not appreciated because the source does not include very few promotional brands. It is the main source of economic growth for remittances abroad. Over the last two years, migration has increased among industrialized and developing countries. It also increases in purchasing power and ensures the highest level of growth and regulation of economic growth.

Those countries which have not prepare enough capitals; they acquire or use finances from other countries to fulfil their objectives like avoiding price rises and funding community expenditure etc. The developing countries are frequently changed these conditions that have shortages in the glows of holding funds that create the country accomplished to attain financial growth. The two features which force the countries to 
its external borrowing are shortages in the stability of expenses and funding shortages in community sector, (Korkmaz, 2015).

In the illuminations of employment, there is significance in importations; nations make rules plus regulation, prepared rules and walls to regulator the global employment (Benito, 2003). To limiting employment among nations prices and duties on trade in goods, pre-defined shares and government procedures and rules is identified as the financial rule named 'Protectionism'. Once the barriers of employment and policies are uninvolved then consuming imported goods are increases significantly. When these barriers are removed the prices of imports get lower and imported goods are risen up to its greater level. The imported goods and international trade make the huge influences and obtains the projecting share in the gross domestic product. In many nations there is a great partisan, community financial status because there are imports enable to access things and facilities to its other countries. Short of imports nations have partial things and facilities inside their limits which have the harmful influence on GDP of the nation.

The South Asia Association for Area Cooperation is the association which is intergovernmental organization and its fellow nations are Pakistan, India, Bangladesh, Afghanistan, Sri Lanka, Bhutan, Nepal and the Maldives. It was founded on 08th December, 1985 in the capital city of Bangladesh. SAARC plays a vital role in promoting the monetary development and provincial incorporation. Above the existences, there has major development in the employment relatives between the seven SAARC followers.

\subsection{Problem statement}

The SAARC budget is one of the fast-paced financial systems in the domain with a high dependence on external aspects, such as foreign currency investment, foreign direct investment, foreign payments, foreign imports and the debt abroad is all about to find out how the impact of these properties on the gas economy is. The effects after finding out about the benefit of negative and negative impact have an impact on financial growth. FDI, overpayments have a major impact on the financial system, while the FPI, debt and imports have a major and negative impact on the economy. These academics point out that the external factor of money and income from funds in the host countries is very important to import to improve financial growth. In particular, the impact of overseas aspects in the economic recovery of the SAARC 
countries is to discover that these assets and fluctuations in these countries result or not. Rehman, (2016). FDI shows an important role in improving the economy. Therefore, the international reception areas are welcomed to this asset as it is beneficial to produce an economy through rental opportunities. Progress in Skills, Better Association and Good Transaction Waqas, Hashmi and Nazir (2015), these students assume that the FPI is a short-term funding that reduces power plants to grow, the FPI helps more than the associated rates. In rising countries, the biggest criteria for maintaining and addressing capital are a real growth rate. In addition, the good monetary situation is also good for the maintenance and recovery of investments. The overpayment is the second largest funding base in host countries, after the foreign investment director protects the import side of the decline to produce Albulescu (2015). High quality impacts on the arrival of bank transfers to GDP and the increase in developed markets includes how these overpayments affect the balance of payments, human capital growth, deposit restrictions, domestic assets, economic movements.

\subsection{Researchobjective}

The study objective is towards finding out the impact of Foreign Direct Investment (FDI), Foreign Remittance (FR), Foreign Import (FI), Foreign Portfolio Investment (FPI) and Foreign Debt (FD) on Economic Growth in SAARC.

\subsection{Researchquestion}

What is the impact of five external determinants Foreign Imports, Foreign Investment Portfolio, Foreign Debt, Foreign Direct Investment and Foreign Funding for SAARC Economic Growth?

\subsection{Scope of the study}

The purpose of the paper is to detrmine the impact of foreign portfolio investment, foreign direct investment, foreign debt, foreign payments and foreign imports on the economic growth of selected SAARC countries, namely Bangladesh, Sri Lanka, India and Pakistan. This paper is contributing significantly in the studies of economic growth in many different ways. This research contains five important capital inflow variables so their effect can be analyzed on the economic growth. This study is using the latest econometric techniques e.g. Panel root test, Panel regression model etc. The study brings a better kind of relationship between dependent and independent 
variables on economic analysis or someone who has to read. The numerical prediction has to tell how the FDI impact, import, debt, GDP and economic growth impacts when these five foreign factors come from selected SAARC countries.

\subsection{Limitation of the study}

The study requires a certain limitation with respect to data. First, the information shown in annual sources, if the record is in the monthly, quarterly and semi-annual reports, so that the probability results are more accurate than the annual data. In some countries data are not offered annually, so all SAARC countries in Pakistan, India, Bangladesh and Sri Lanka are completed. The data were selected from 1992 to 2015. Secondly, due to money-related functions, access to paid data and materials is difficult to help researchers find additional facts under dependent and independent variables.

\section{Literature review}

\subsection{Theoretical background}

Many previous investigations have shown that high FDI impacts on monetary boom Ibrahim, Kalaivani and Srinivasan (2011); Frimpong and Oteng-Abayie (2006); Almfraji (2014). Foreign direct investment represents a dynamic part of the world's budget. Specifically, it will help to declare or strengthen the host country's budget. Today, in most cases, it is a commercial business agreement outside of the country to start a commercial company in the United States by its union or individual. Today the United States of America wants to forget about the necessary responsibilities or commercial groups. In her, in general, her association with the necessary countries provides employment, trade abroad and a good arrangement. Any FDI investment will receive significant statistics and the new technology of the country's clothing. The government must enforce these policies that benefit the FDI of host countries. It is understood that many developed and underdeveloped international areas want to be a financial guide that benefits the development of money.

The estimation of economists is diversified in the relationship between economic development and foreign capital, mainly FPI. Describing some of the benefits of foreign portfolio investment for developed countries, previous studies have shown that the FPI is helping to expand the causes of external financing, which reduces capital costs and supports the improvement of markets national, so that the direct aid for the development, whereas the FDI help to grow to promote the GDP Abdalla and 
Dafalla (2011); Todea i Plesoianu (2013). The additional indicator should be organized, and many studies also emphasize the association between short-term capital and economic volatility due to its hypothetical nature, arguing that it is unlikely that economic growth will increase in the emerging markets short-term capital stock entries due to the great instability and market. Although previous studies have discovered the benefits and losses of foreign capital flows, it is contributing the relationship between FPI and GDP in many areas has not been studied thoroughly. Most of the literature focuses on professional and the confidence of foreign capital and argues its dynamics under economic disorder. The results of many scholars of the relationship between capital flows and GDP differ from some studies that positive aspects are concerned, although others underline the negative traits.

During the past year, the employee has sent a lot of attention to academics and policy makers. Transfers also provide a basis for improving the country's economy. With this installation, an external sends money to its own country. Since 2000, remittances have made little progress in the economies of small and developing countries. The positive impact of the transfer of payments on developing and developing a developed country covers the impact of remittances from technical development, human capital development, level of employment and profits, differences in economic actions, exports, restrictions on foreign credit, foreign exchange and currency exchange Karamelikli and Bayar (2015); Sondaar and Chern (2009); Jackman and Moore (2009).

In historical research, external debt has a negative impact on the economy, since debt a country gains from other countries to achieve targets Adegebite and Ayadi (2008); Chowdhury (2001). Developed countries do not recognize subsidies as economic growth due to the increase in their output and income. The shortfall in the payment balance and the public sector finances do not cause any shortfall in the foreign loan impact. The countries can do so in the field of fiscal policy, as the government will increase the tax burden of interest for taxation.

The scientist concludes that imports have effective and negative economic consequences. Imports will help the United States to use goods and facilities that are not in the country. In most countries, imports of objects are an essential contributor to GDP Banito (2003); Siddiqui and Iqbal (2005). The world's change has an essential political, social and financial significance from many countries. Enter components of 
international locations goods and services from other countries. Other studies have discovered that imports have a terrible impact on GDP because the US imports many goods and services, and things that soon come into line with these gadgets. Due to the massive imports, the request of host countries, the import of goods and services, is a huge amount of cash day by day for the country's cash crop, so it has poor financial impact.

\subsection{Empiricalstudies}

The researchers took advantage of the integration of the console to record and GMM as a tool test. There are six variables in the study; GDP is based on remittances, inflation, government consumption, industrial openness, per capita income as impartial variables. The effects show that remittances and industrial retailers have a huge impact on GDP, while preliminary revenue from capital, public consumption and inflation charges have a poor impact on GDP. The researchers encouraged the remittances that are required with the help of foreign currencies, lead to economic growth, human capital, cash and significantly increase investment in the country to pay the increase in remittances, people They are power and also increases the level of income decreases inflation and unemployment due to long-term reserves at a single moment.

Rehman (2016) investigated GDP and FDI: They observed that the Pakistani certificate data were transmitted from the moment of harvesting from 1970 to 2012. In the research, a scientist uses a model of error correction Vector as a research tool. the scientists used five variables in the study; GDP like variable and dependent rates of literacy, human capital exports and FDI as variables. The results suggest that human capital, foreign direct investment and exports have a positive impact on GDP, where literacy rates have a terrible impact on GDP. Academic note that direct foreign investment, financed by countries for economic growth, always knew that the people of the new top team in the country and acquired a large number of opportunities for people to create an excellent profile It works with additional electrical energy for staff and students, then future ones, who have to work to use the new applied sciences, which go through economic growth.

Academic Haider, Khan and Abdullahi (2016) are studying the reasons of FPI and their impacts on China, the use of records from the ongoing ranges of 1997-2014. Scholars use OLS regression as a search tool. There are five guidelines of search; 
Foreign direct investment is a based variable, whilst GDP, exterior debt, demographic development, exchange fee and direct funding backyard the united states of America as an impartial variable. The outcomes exhibit that exterior debt and GDP have a robust effect on FPI, whilst the population growth and change charge have a wonderful have an impact on FPI. Foreign direct investment has a poor influence on overseas investment. Researchers argue that cash earnings can be bolstered by property that may be the purchase of components or portions and participation in the USA when the economic system is enhanced in the country.

Researcher Nellis and Papa Georgiadis (2016) observe the conclusion of FDI and its clear implementation force on economic growth through the use of panel data from 42 developing countries in the period 1998-2011. The researcher uses GMM, OLS and FE as a research tool. In the search there are seven variables; GDP per capita as a dependent while the development of secure capital, FDI, study and growth, human capital, inflation rates and governmental strength as independent variables. The outcomes that FDI, strength policy, human capital, study and growth and development of fixed capital have a positive impact on GDP, provided that the inflation rate has a negative impact on GDP. The scholar suggested that the obvious outcome on economic growth offers care and security between the functions surrounding the implementation system that give control and establishments.

The researchers Ajide and Adeniyi (2015) examine remittances, the loss of exit from institutions and organizations through the use of data from the 1996-2012 framework. Academics use the usual time approach (GMM) as a means of research. The scientist chooses three variables; Standard deviation of GDP as dependent variable and variable of remittances and independent variable organization. The result shows that selective elections have an impact on GDP. The scholar suggests that the unrelated negative impact of progress is close to the lack of deficiency and because it creates the political issue of a government problem that will end the growth of the budget that must be done.

Korkmaz scientist (2015) examined the relationship between currency growth and debt exchanges in Turkey that dumped data from time series from 2003 to 2014. In the study, the VAR approach is used to identify relationships. In study, the scholar uses two variables; GDP is dependent and external as an independent variable. The effect shows that, at the specified stage, debt outweighs a positive relationship and the effects 
of monetary growth. The academic says that the use of private and foreign debt to debate the growth of the country's currency, so that the country's development will occur if it reduces the internal source of the country associated with other countries.

Waqas, Hashmi and Nazir (2015) investigators found the instability of foreign portfolio investment more problematic macroeconomic in the nation of South Asian nations, the use of panel records from 2000 to 2012. Researchers used the GARCH model. There are seven variables in this study; GDP and create interest rates, inflation, FDI, exchange rates, FPI and industrial catalogs as independent variables. Indication of the result that industrial production, FPI, FDI and exchange rates have an effective effect on GDP and that inflation and interest rates have a negative influence on GDP. The researchers suggest that the FPI is no longer stable in rural areas; It's short-term financing. FDI reduces the volatility of the FPI as its income is low compared to the amount of the liquidity debt.

Tahir, Khan and Shah (2015) followed the 1977-2013 period in remote direct speculation in Pakistan, the transfer of foreign money, economic development and foreign trade. The concentrated OLS has used the recurrence analysis as a research tool. Four factors were selected in the examination investigation; GDP and import as dependent variables, liquidation and FDI as independent variables. Imports and GDP: while the positive and long-distance connectivity of GDP; imports have a negative impact on GDP. The researcher has suggested that the approach to provide the benefits of the legislative body, the agreement and the FDI should be directed to the country in order to take this problem into account, taking into account the objective end to create the economy.

Noman, Rahman and Naka (2015) analyzed the investment of the increase of FDI and FPI with information from 45 countries until the period 2001-2009. In the study, the researcher visited OLS as a review tool. The researcher used eight factors in the search; FPI and FDI as dependent variables, work acceptance, transparency related to money, return of the showcase of local value, rate of growth, de facto exchange rate, growth of GDP as autonomous factors. The result shows that the variable definitively decides on FDI and FDI, but the rate of increase is affected negatively. The researcher has argued that the transversal threshold initiative today plays an important role in building the economy with reasons of need. The fund has a negative impact, therefore, there is a reasonable return to increase the country's financial plan. 
Michael and Thankgod (2014) examined the growth of Nigeria's portfolio and foreign investment using time series data from 1986-2011. Researchers use the station, errorfinding and integration procedures. The study has 5 variables; Current Domestic Product as a Dependent Variable while the Inflation Rate, Net Investment in External Portfolio, Trade and Fairness Rate and Market Capitalization as an Independent Variable Trade Scoreboard. The Honesty Rate, Portfolio Investment, market capitalization showed a positive and long-term position compared to GDP but is a negative and short-term impact compared to the inflation rate to GDP. The scholar suggests that the FPI must be fully met in order to gain a better manpower. Institutions need to make a responsible policy towards the country's shareholders.

The researchers Chaudhary and Mahmood (2013) study parents between FDI and GDP in China with data from 1985 to 2009. The technique of integrating the ARDL is used as a research tool. There are four variables in the study; The dependent variable is GDP and the independent variable is FDI, gross fixed capital formation, consumer costs. All independent variables have a positive effect on the dependent variables. The scholar suggested that FDI have a wealth of wealth in developed and underdeveloped countries, their impact on the growing economy in exports, manufacturing and employment.

Hye (2012) investigates imports, increases in money and sales in China through data series from the years 1978-2009. The examiner uses retardation propagation of automatic regression (ARDL) as a research resource. The scientific study selected three factors: import, export and GDP that were identified among them. The result shows that there are two levels of cuts and exports of GDP, exports, GDP, GDP and imports, imports and GDP. Scientists recommend that the acceptance of trade liberalization stimulate the budget. Exports should be better than imports, so the budget will improve.

Srinivasan, Kalaivani and Ibrahim (2011) study monetary growth and foreign direct investment in the SAARC nations to use information from schedules between 1970 and 2007. The researchers use Johannsen to formulate and correlate Vector errors as a research resource. The investigator uses two variables; GDP and foreign direct investment as dependent as independent variable. we estimate that Johannsen's result is a proof of a long-term relationship with a dependent variable in the case of the SAARC countries, and the results of VECM have shown that there is a long-term relationship between SAARC countries, with the exception of India. There is a small 
relationship with India. the investigator recommends to the SAARC countries to adopt a sound policy to increase economies to increase human capital, to improve the capacity of the local economy, which is based on and strengthens economic power, benefits from foreign direct investment.

Adenutsi (2011) study the global migrant remittance, economic development and endogenous development in Ghana by way of the usage of time collection information of period 1987 to 2007. In learn about equilibrium-correction instrument figure is been used as an investigation instrument. In lookup eight variables are used: financial increase as based variables and remittance, human capital development, economic openness, overseas direct investment, inflation, Investment, and monetary deepening. Outcome recommends that the human improvement economics, investment, economics openness, FDI, remittance have tremendous lengthy run relation with financial development. Inflation, asset and financial extending have poor lengthy run relative through established variables. Scientist recommended that the remittance can be militarized from aboard honestly defined by the monetary growth and remittance straight impact short and long term on economic development.

The three researchers Jackman and Carigwell and Moore (2009) disclose remittances and statistics of the loss of money they have taken from tiny island developing states with flat records on 20 islands between 1986 and 2005. Scientists use mass cross sections and frequent plate influences as a search tool. In the survey we selected five variables. The dependent variable is remittance and discrete variables are the transfer to GDP, unrelated consumption, economic loss, and lack of investments. The result suggests that an inadequate change has a significant effect on remittance. On the lookout, it should be noted that the references used for the United States of America, fully paid for remittance, should be examined and presented in a proper manner and should be a forecast of the remittance activity.

Adegbite, Ayadi and Ayadi (2008) studied the effect of Nigeria's external debt on economic growth by consuming time series data from 1980 to 2005. Academics choose the smallest general places and the smallest ordinary squares than their study tools. In this study, eight variables were named, GDP as a dependent variable and the growth of exports, private investment, savings, debt service variables, public capital expenditures, external debt values and the variables that are independent of the exchange rate. The results suggest that savings, exchange rates, savings and stocks of external debt have a negative impact on GDP, while investment expenditures, export 
development plus facility variables of debt have a positive impact on GDP. Researchers recommend that other debts or nations need to increase their exterior deposit or trial procedures and debt organization agreements.

Pattillo, Porison and Ricci (2002) view claims of overseas debt and growth through the use of huge amounts of facts from a data from 93 countries that exist between 1969 and 1998. The researcher used regression analysis and many debt indicators. studies worked on eight variables; GDP per capita as dependent variables and initial per capita incomes, population growth, investment rates, school enrollment, business growth, opening and price balance of GDP. The result suggests that some variables have a negative value and some variables have a large effect on GDP. On the other hand, the ratio between financing, exchange growth, education levels, fiscal equilibrium and GDP and opening up has a huge impact on GDP, the researcher recommends that excessive debt should limit the compensation for booming.

Siddiqui and Iqbal (2005) considered the benefits of improving the use of Pakistan in the period between 1972 and 2002. They choose the consultation interview as a test tool. In the study they selected several Variables; The cash flow of GDP is the difference between the protection and growth of trade, population growth and the growth of the bank as a free brand. The results indicate that population fluctuations and cash flow are effective in GDP growth, but GDP growth is very effective. Researcher indicates that the difference in variation differs, but the most implicit links are to achieve the benefits of GDP. Countries that benefit from free will do not grow more GDP.

\section{Research methodology}

\subsection{Research approach}

In this research the quantitative approach was used. Quantitative research deals with the numerical data and simplifies with the group of people and to explain the facts of the observer Bordens and Abbott (2002). The data which are gathered through a survey, questionnaire and many other factors is called Quantitative research. When the data was gathered the researcher evaluates or analyzes the data for its validation. It reduces the risk and enhance rate of return. The researcher uses different numerical and statistical approaches to measure and analyze the data. 


\subsection{Research purpose}

In this study the explanatory research has been used. The explanatory research is used for findings problems solution by suggest the hypotheses Srinivasan, Kalaivani and Ibrahim (2011). Secondary source of data is used in the study because it usually focuses the relation of independent variable on dependent variable. The goal of the research is to classify, or describe the condition.

\subsection{Research design}

The correlation design was used in this research. The correlation design is the quantitative research method. In this we link and correlate between two or more variables to get the relations between variables. Correlation helps the other researchers for further research on the previous topics. This research method has got more access data than the experiment because this method is easily applicable to daily life. It also allows the researchers to analyze the strength and direction of a relationship so the past studies can narrow the findings.

\subsection{Data source}

There are two types of data collection one is primary data and the second is secondary data. Primary data is collected from first hand like filling questionnaires and through interviews while the secondary data was written in the past by some researchers' studies or published in an article.

In this study we used a secondary data tool for collection of data source, as it was easily available on the authentic website of World Bank (www.worldbank.org).

\subsection{Sample data and period}

This study is conducted in the context of Pakistan, India, Sri Lanka and Bangladesh and data have been collected of 24 years from the period 1992-2015. Yearly panel data has been collected by using secondary sources from the World Bank website.

The reason of selecting this period is the occurrence of drastic changes in world's economy so that the effect of selected variables can be clearly seen and analyzed. Also, this selection of a long time period helped in developing detailed results with multiple evidences so that more accurate future predictions can be made. 


\subsection{Statistical techniques}

To check the Impact of Foreign direct investment, foreign debt, foreign portfolio investment, foreign remittance and foreign import on economic growth different econometric techniques and statistical techniques are applied.

Panel unit root test: Panel unit root test is used to check the variables are stationary or not on at level or on first difference. If all variables are not stationary at level then it means there is a trend among the variables but all variables are stationary at first level of difference then there is no trend among the variable.

Pedroni Panel Co-integration: This test is used to check the relationship among the variables for long run.

Panel regression analysis: Panel regression analysis has two methods fixed effect and random effect model which is used to check the impact of dependent variable on independent variables so the Hausman test has been used for appropriate model.

Granger causality test: Granger causality test is used to check or find out the causality among the variables

\subsection{Statisticalmodel}

$$
\mathrm{GDP}=\alpha+\beta 1(\mathrm{FDI})+\beta 2(\mathrm{FPI})+\beta 3(\mathrm{FD})+\beta 4(\mathrm{FR})+\beta 5(\mathrm{FI}) ?
$$

Where; GDP is gross domestic product; FDI is Foreign direct investment; FPI is foreign portfolio investment; FD is Foreign Debt; FR is Foreign Remittance; FI is Foreign Import; a is Coefficient and? is Error term.

\subsection{Model hypothesis}

H01: FDI has an insignificant impact on GDP

H02: FPI has an insignificant impact on GDP

H03: FD has an insignificant impact on GDP

H04: FR has an insignificant impact on GDP

H05: FI has an insignificant impact on GDP 


\subsection{Variable description}

To conduct the study there are six variables; GDP as dependent Variables where as foreign imports, foreign remittance, foreign debt, foreign portfolio investment and foreign direct investment as independent variables.

Gross domestic product: GDP is the standard measure of the value of final goods and services produced by a country during a period. Production by foreign companies in that countries also include in GDP circle.

Foreign direct investment: FDI an investment in the form of controlling ownership in a business in one country by an entity based in other country.

Foreign portfolio investment: FPI an investment by foreigner by depositing money in a country bank or make purchase in bond markets, stock and share market and securities.

Foreign debt: It is the component of total debt held by creditor of foreign countries the debt can take the form of money owed to private bank, outside government or global financial institution.

Foreign remittance: Peer to Peer transfer of funds by a foreign worker to his own country.

Foreign import: Bring good and services into a country from another country.

\section{Data analysis}

\subsection{Descriptive statistics}

According Saunder (2012), there is descriptive and inferential statistics. In this research descriptive statistics is used to organize, summarize and make sense of data. Descriptive statistics describe the variable so it is performed before analysis of any data.

Table 1 provides descriptive statistics of the study. The variables taken in the study are Gross domestic product (GDP), foreign direct investment (FDI), foreign portfolio investment (FPI), foreign imports (FI), foreign remittance (FR) and foreign debt and 
in descriptive statistics Mean, minimum, maximum, standard deviation and number of observations are included.

Table 1 : Descriptive statistics

\begin{tabular}{|c|c|c|c|c|c|c|}
\hline & $\begin{array}{c}\text { GDP per } \\
\text { Capita }\end{array}$ & $\begin{array}{l}\text { FDI \% } \\
\text { of GDP }\end{array}$ & $\begin{array}{l}\text { FPI \% } \\
\text { of GDP }\end{array}$ & $\begin{array}{c}\text { FI \% } \\
\text { of GDP }\end{array}$ & $\begin{array}{c}\text { FR \% } \\
\text { of GDP }\end{array}$ & $\begin{array}{l}\text { FD \% } \\
\text { of GDP }\end{array}$ \\
\hline Mean & 3.781 & 1.098 & -0.604 & 24.203 & 5.062 & 33.252 \\
\hline Maximum & 8.754 & 3.668 & 1.270 & 49.620 & 10.587 & 24.176 \\
\hline Minimum & -2.289 & 0.004 & -8.447 & 9.424 & 0.987 & 4.382 \\
\hline Std. Dev. & 2.219 & 0.764 & 1.265 & 10.285 & 2.476 & 29.257 \\
\hline Observations & 96 & 96 & 96 & 96 & 96 & 96 \\
\hline
\end{tabular}

Above table show that GDP mean is 3.781 with maximum value 8.754 and with minimum value -2.289 . Standard deviation is 2.219 with total 96 observations. Moreover, FDI mean is 1.098 with maximum value 3.668 and minimum value 0.004 . Standard deviation is 0.764 with total 96 observations. Furthermore, FPI mean is 0.0604 with maximum value 1.270 and minimum value -8.447. Standard deviation is 1.265 with total 96 observations. Furthermore, FI mean is 24.203 with maximum value 46.620 and with minimum value 9.424 . Standard deviation is 10.285 with 96 observations in total. Furthermore, FR mean is 5.062 with maximum value 10.587 and with minimum value 0.987 . Standard deviation is 2.476 with 96 observations. Lastly FD mean is 33.252 with maximum value 24.176 and with minimum value 4.382 , standard deviation 29.257 with total 96 observations.

\subsection{Panel unit root test}

To find out the stationary among the variables, panel unit root has been used. Panel unit root is a statistical technique which tells researcher that there is a trend among the variables or not whether the variable is unit root or stationary. All variables GDP, FDI, FPI, FI, FR and FD in the research are tested for stationary by conducting augment Dickey-Fuller test (ADF) unit roots tests and Im, Pesaran, Shin. Rajaguru and Thangavelu (2004) explain that ADF correct the serial correlation for higher order adding different lagged variables. Im, Pesaran and Shin (2003) assume autoregressive between countries. In panel unit root test, we will find that the trend is at level or at 1st difference. On level if data is non-stationary so the variable is having 
trend and on 1 st difference if the data is stationary so variable is having no trend. So, when the data will have no trends on stationary so researcher will further to for other tests. The null hypothesis of unit root is the variable having unit root Christopoulos and Tsionas (2004). Panel unit root test is applied on the variables from 1992 to 2015 by using Eviews 9. Table 2 is having two estimations which are ADF- Fisher Chisquare and Im, Pesaran and Shin W-stat with their statistical level.

\section{Table 2: Panel unit root test}

\begin{tabular}{|c|c|c|c|c|c|}
\hline \multirow{2}{*}{ Variable } & \multirow{2}{*}{ Estimates } & \multicolumn{2}{|c|}{$\mathrm{I}(0)$} & \multicolumn{2}{|c|}{$I(1)$} \\
\hline & & $\mathrm{C}$ & $\mathrm{C} \& \mathrm{~T}$ & $\mathrm{C}$ & $\mathrm{C} \& \mathrm{~T}$ \\
\hline \multirow[t]{4}{*}{ GDP } & ADF - Fisher Chi-square & 6.869 & 8.0825 & 24.689 & 14.451 \\
\hline & & $(0.550)$ & $(0.425)$ & $(0.001)$ & $(0.07)$ \\
\hline & Im, Pesaran and Shin W-stat & -0.336 & -0.673 & -3.149 & -1.717 \\
\hline & & $(0.368)$ & $(0.250)$ & $(0.000)$ & $(0.042)$ \\
\hline \multirow[t]{4}{*}{ FDI } & ADF - Fisher Chi-square & 7.513 & 3.89 & 26.265 & 28.624 \\
\hline & & $(0.482)$ & $(0.866)$ & $(0.000)$ & $(0.000)$ \\
\hline & Im, Pesaran and Shin W-stat & 1.112 & 1.671 & -3.278 & -3.574 \\
\hline & & $(0.867)$ & $(0.952)$ & $(0.000)$ & $(0.000)$ \\
\hline \multirow[t]{4}{*}{ FPI } & ADF - Fisher Chi-square & 7.101 & 6.176 & 13.686 & 23.832 \\
\hline & & $(0.525)$ & $(0.627)$ & $(0.09)$ & $(0.002)$ \\
\hline & Im, Pesaran and Shin W-stat & -0.571 & -0.512 & -1.6774 & -2.803 \\
\hline & & $(0.283)($ & $(0.3041)$ & $(0.046)$ & $(0.002)$ \\
\hline \multirow[t]{4}{*}{ FI } & ADF - Fisher Chi-square & 4.90 & 7.693 & 33.776 & 23.572 \\
\hline & & $(0.767)$ & $(0.464)$ & $(0.00)$ & $(0.002)$ \\
\hline & Im, Pesaran and Shin W-stat & 0.456 & 0.232 & -4.235 & -2.896 \\
\hline & & $(0.676)$ & $(0.592)$ & $(0.000)$ & $(0.001)$ \\
\hline \multirow[t]{5}{*}{ FR } & ADF - Fisher Chi-square & 5.00 & 6.849 & 31.686 & 23.555 \\
\hline & & $(0.757)$ & $(0.552)$ & $(0.001)$ & $(0.002)$ \\
\hline & Im, Pesaran and Shin W-stat & 0.654 & 0.126 & -4.093 & -3.062 \\
\hline & & $(0.743)$ & $(0.550)$ & $(0.000)$ & $(0.001)$ \\
\hline & & 8.755 & 10.731 & 32.899 & 23.095 \\
\hline \multirow[t]{3}{*}{ FD } & ADF - Fisher Chi-square & $(0.363)$ & $(0.217)$ & $(0.001)$ & $(0.003)$ \\
\hline & & -0.813 & -1.136 & -4.030 & -3.057 \\
\hline & Im, Pesaran and Shin W-stat & $(0.207)$ & $(0.127)$ & $(0.000)$ & $(0.001)$ \\
\hline
\end{tabular}


In the above table both ADF and Im, Pesaran and Shin W-stat tests of unit roots are applied to intercept and intercept and trend. At level all variables are non-stationary as they having a trend. So, the Ho is rejected and H1 is accepted. So, there is a unit root among these variables. However, at 1 st difference all the variables are stationary as they don't show any trend. So, the Ho is accepted and H1 is rejected. So, there is no unit root among these variables all are stationary at 1 st difference. Now the entire variables are stationary so we run cointegration test to check long run relationship among these variables.

\subsection{Panel Co-integration test}

After panel unit root test when all the variables are non-stationary at level and stationary at 1st difference so we can now check relationship among the variable by using Pedroni co integrated test (1997). This test tells us the long run relationship among the variables or variables is co-integrated or not (soreson, 1995). The co integration theory tell us about innovation in the field of economics by statically theories and mathematically which help to forecast about the variables trend that there is a relation or not. Bellow table 3 provides panel cointegration using Pedroni (1997). The null hypothesis of cointegration test is there is no cointegration among variables (pedroni, 2004; Asteriou \& price, 2005; persyn \& westerlund, 2008).

Table 3 : Panel cointegration test (Pedroni, 1997)

\begin{tabular}{lcc}
\hline \multicolumn{1}{c}{ Estimates } & Statistics & P-Values \\
\hline Panel v-Statistic & -0.288 & 0.613 \\
Panel rho-Statistic & -0.042 & 0.483 \\
Panel PP-Statistic & -6.092 & 0.000 \\
Panel ADF-Statistic & -2.934 & 0.001 \\
Group rho-Statistic & 0.906 & 0.817 \\
Group PP-Statistics & -7.868 & 0.000 \\
Group ADF-statistics & -2.427 & 0.007 \\
\hline
\end{tabular}


Panel co-integration results shows in table 3 that out of seven estimations, four estimations reject the null hypothesis of no co-integration by having prob. value less than 5\%. Panel v-Statistics Value 0.613, Panel rho-Statistics value 0.483 and Group rho-statistics value 0.817 have prob. value greater than $5 \%$ so they accept null hypothesis of no co-integration that variables doesn't hold any relationship among them but Panel PP-Statistics value 0.000, Panel ADF-statistics value 0.001, Group PPStatistics value 0.000 and Group ADF-Statistic value 0.007 have prob. value less than $5 \%$ so they reject the null hypothesis and variable are co integrated among them and hold long run relationship. Hence it is statistically proven that more variables are rejecting null hypothesis so the co integration exist in the model and all the variables are having long run relationship among them.

\section{Table 4: KAO residual cointegration test}

\begin{tabular}{|c|c|c|}
\hline Estimates & t-Statistics & P-Values \\
\hline $\mathrm{ADF}$ & -3.384 & 0.0004 \\
\hline
\end{tabular}

Similarly, in the table 4 of Kao Residual Co-integration test the prob. Value is less than $5 \%$ which is 0.0004 so the null hypothesis is rejected of no co-integration. This table explains that all the variable Gross domestic product, foreign direct investment, foreign portfolio investment, foreign import, foreign remittance and foreign debt are co integrated and having long run relationship among them. From above two table we concluded that there the co integration exist among the variables.

\subsection{Multiple regression analysis}

In panel regression model there are two methods which help to identify the relationship among the dependent variables and independent variables. The methods are fixed and random effect. To find out which method is appropriate for the model so we use Hausman test to find out. Hausman test (Hausman 1978) is a test used in panel data analysis to discriminate between fixed and random effect. The null hypothesis of Hausman test is random effect model and alternative is fixed effect model. 
Table 5: Hausman test

\begin{tabular}{cccc}
\hline Test Summary & Chi-Sq Statistic & Chi-sq. d.f & Prob. \\
\hline Period Random & 9.574 & 5 & 0.088 \\
\hline
\end{tabular}

The table 5 of Hausman test shows that the prob. Value is less than $10 \%$ which is 0.008 so we reject null hypothesis and go for the alternative. Alternative hypothesis suggests that the appropriate method for the data is fixed effect.

Table 6 of fixed panel least square method tells us the relationship of independent variables on the dependent variable that these variables positively or negative impact each other. The independent Variables are foreign direct investment, foreign debt, foreign remittance, foreign portfolio investment and foreign imports and dependent variables is Gross domestic product for these four countries are selected from SAARC countries which are Pakistan, India, Sri Lanka and Bangladesh from the time period 1992 to 2015.

Table 6: Panel least square

\begin{tabular}{lcccc}
\hline \multicolumn{1}{c}{ Variables } & Coefficient & Std. Error & t-Statistics & Prob. \\
\hline Constant & 0.135 & 0.793 & 0.170 & 0.865 \\
FDI & 0.0455 & 0.008 & 5.100 & 0.000 \\
FPI & -0.422 & 0.178 & -2.371 & 0.020 \\
FI & 0.018 & 0.029 & 0.624 & 0.534 \\
FR & 0.338 & 0.154 & 2.186 & 0.032 \\
FD & -0.260 & 0.400 & -0.649 & 0.518 \\
\hline
\end{tabular}

F-Statistics (Prob.) $=2.978(0.000) ;$ Adj. $\mathrm{R} 2=0.654 ;{ }^{*} \mathrm{p}<0.05$ Durbin Watson Stat 1.667 Dependent Variable: Gross Domestic Product (GDP)

Above table of fixed ordinary least square methods explains the relationship among variables. Model illustrate that Foreign direct investment, foreign Imports and foreign remittance have positive impact on gross domestic product because the coefficient values are in positive which are FDI (0.135), FI(0.018) and FR(0.338) other two independent variables Foreign portfolio investment and Foreign debt have negative impact on gross domestic product because the coefficient values are in negative which is FPI (-0.422) and FD (-0.260) .Model shows that if Foreign direct investment, Foreign Import and Foreign remittance increases in Pakistan, India, Sri Lanka and 
Bangladesh so economy will grow in these countries where are Foreign debt and Foreign portfolio investment increase in the these countries so economy will decreases. The overall model is significant because the F-Statistics prob. Value is less than $10 \%$ which is 0.000 . R2 Tells us the model accuracy which is 0.654 this mean $65.4 \%$ independent variables explaining the dependent variables. Durbin Watson stats tells us the model have auto correlation or not. The value of Durbin Watson stats is 1.667 which is closest to 2 which mean there is no autocorrelation.

From the above results it shows that the first independent variables which shows positive impact on GDP is foreign direct investment. If $1 \%$ increases in FDI so 0.0455 $\%$ of GDP will increase. The result is supported by numerous studies that also suggested that FDI have positive impact on GDP Inflow of FDI in these countries rapidly increases day by day because of advanced technology, reduction in various regulatory, communication advance, trade and barrier in cross countries investment. Second independent which show negative impact on GDP is foreign portfolio investment. If 1 percent in FPI increase then GDP will decrease by $-0.422 \%$. The transmission mechanism between FPI and GDP has been summarized in the previous studies. FPI cannot bring employment that is one of the biggest reasons that's why these countries do not welcome these investments as the population of these countries are very high and employment rate too. Second reason is the Financial market are not that much high standard that these investors come and invest in these countries however FPI can influence GDP through its contribution in developing the local financial markets. FPI initiates informational, regulation and institutional changes because foreign participants demand timely quality information and minority right protection, as well as adequate trading and market regulations; it improves the quality and efficiency of financial sector and helps to boost up the domestic economy. Third independent variable which shows positive impact on GDP is foreign Remittance. If $1 \%$ FR increases so GDP will increase by $0.338 \%$ many past studies also suggest these results. Remittance is second most import source of foreign investment in a host country. South Asian worker demands increasing day by day. Within South Asia, Bangladesh, India, Pakistan and Sri Lanka have been the main suppliers of migrant workers who are spread over almost all over the world because of their rich in labor force because the population of these countries increasing day by day. Most of this worker move to Middle East in oil rich countries e Remittances sent by these migrant workers to their home play vital role in the betterment of the economy. Forth independent variables which show positive impact on GDP is foreign imports. If $1 \%$ of import increases so GDP will increase by $0.018 \%$ and many studies also concluded 
their research with imports positively impact on GDP. Imports provide goods and services from the other nation if the country does not import so it restricts to only the product and services within the country. The last independent variables which have a negative impact on GDP are foreign debt. If foreign debt increases by $1 \%$ so GDP will decrease by $0.260 \%$ and many studies also suggests these results. External debt shows problem for South Asian countries. The possibility of sustainability of debt and repayment of debt servicing will become very weak rather impossible in the future. In the light of opportunity cost, this situation results in lesser domestic resources being available for other development activities e.g. education, health and human development. Due to external debt burden government increases taxes in order to pay installments of these debt these taxes increase in a huge percent which peoples of these countries cannot afford to pay so debt negatively impact GDP. As South Asia is one of the poorest regions of the world.

\subsection{Grangercausality tests}

Clive granger (2003) proposed the Granger causality is way to find out cause and effect and forecasts among dependent and independent variables. Table 7 show the model of granger causality test with null hypothesis, F statistics and prob. Value.

\section{Table 7: Granger causality tests}

\begin{tabular}{lll}
\hline \multicolumn{1}{c}{ Null Hypothesis: } & F-Statistic & Prob. \\
\hline FDI does not Granger Cause GDP & 0.371 & 0.690 \\
GDP does not Granger Cause FDI & 5.154 & 0.007 \\
FPI does not Granger Cause GDP & 0.167 & 0.850 \\
GDP does not Granger Cause FPI & 2.138 & 0.124 \\
FI does not Granger Cause GDP & 1.318 & 0.273 \\
\hline GDP does not Granger Cause FI & 6.338 & 0.002 \\
FR does not Granger Cause GDP & 0.635 & 0.532 \\
GDP does not Granger Cause FR & 0.736 & 0.482 \\
FD does not Granger Cause GDP & 3.586 & 0.032 \\
GDP does not Granger Cause FD & 0.204 & 0.815 \\
\hline
\end{tabular}


In the above table of granger causality test the relation between GDP and FDI is unidirectional because FDI doesn't Granger GDP because the prob. Value is greater than $10 \%$ which is 0.690 but GDP does granger FDI because the prob. Value is less than $10 \%$ which is 0.007 . GDP and FPI don't show any direction because both the variables don't granger each other because of their Prob. Value greater than $10 \%$ which is GDP Prob. Value 0.124 and FPI Prob. Value is 0.850 . GDP and FI is showing unidirectional relationship because FI doesn't granger GDP because the prob. value is greater than $10 \%$ which is 0.273 but GDP does granger FI because of prob. Value less than $10 \%$ which is 0.002 . GDP and FR doesn't show any direction relationship among them because both the variables don't granger each other because of their Prob. Value which is greater than $10 \%$ which is GDP prob. Value is 0.532 and FR prob. Value 0.482. lastly FD and GDP having unidirectional relationship because FD does granger GDP because of their prob. Value which is less than $10 \%$ which is 0.032 and GDP and FD don't granger each other because their prob. Value is greater than $10 \%$ which is 0.815 .

\section{Conclusion and recommendations}

\subsection{Conclusion}

The study is based on to find out impact of Foreign Direct Investment, Foreign portfolio investment, foreign debt, foreign imports and foreign remittance on economic development of SAARC countries. For this data is collected from the period 1992 to 2015 in total 24 years data been used in the research of top four developing countries of South Asia namely Pakistan, India, Sri Lanka and Bangladesh from world bank website. The objective of the study is to find out positive or negative impact of independent variables on dependent variable in the study the dependent variable is GDP whereas FDI, FPI, FI, FR and FD are independent variables. To find out the finding and relationship of the variables we use econometric view test. Test includes panel unit root test, panel co-integration test, panel ordinary least square method and granger causality.

Firstly, panel unit root test has been used to find out the trend of the data if there is a trend so the variables are non-stationary. If there is no trend so the variables are stationary. ADF - Fisher Chi-square and Im, Pesaran and Shin W-stat is been used in the panel unit root test. Result suggested that all the variables are non-stationary at level which mean there is a trend among variables but at first difference all the 
variables were stationary. After all the variables are stationary so panel co-integration test has been applied to find out long run relation between variables. Pedroni (Engle -Granger based) and Kao (Engle-Granger based) suggested that there is a long run relationship among the variables. Thirdly to find out the impact between dependent and independent variables we used panel ordinary least square method. OLS are of two types fixed effect and random effect. To find out which method is appropriate, Hausman test is used. Hausman test suggested running the data on fixed effect. The result of fixed effect shows that foreign direct investment, foreign import and foreign remittance has positive impact on Gross domestic product. So, when FDI, FI and FR increase GDP will also increase. Whereas the results show that foreign portfolio investment and foreign debt has negative impact on GDP. So, when FPI and FDI increase so GDP will decrease. Finally, Granger causality is applied to find out causal relation among variables result suggested that foreign direct investment, foreign import and foreign debt on GDP have unidirectional relationship where as foreign portfolio investment and foreign remittance doesn't have any directional relationship. If foreign capital and cash inflows in a host country is been properly used so it will give positive output and GDP will increase.

\subsection{Policyimplication}

Following are the policy implications to the state administrators, governmental agencies and economists of South Asian countries especially.

The Government should attract FDI through ensure better law and condition, business friendly environment, resolve issue of power storage and other condition which will boast motivation level of the investor to invest in these countries.

Remittance is second best sources of foreign financing in the host countries mostly Pakistan, India, Sri Lanka and Bangladesh are working in gulf countries and sending huge amount so policy makers should make such policies that these workers easily send their money to their home so that economy will be grow.

Government should make such policy which benefits capital market for foreign worker which will enhance the portfolio investment and economy will grow.

Imports play one of the important roles in the economic development of the host countries especially if they have capital goods new technology, ideas, equipment's. 
These countries should focus on importing capital goods and new technologies rather than consumable item.

Government should make proper management, debt management structure and decision-making process in order to utilize this debt in a progressive field which give huge outcome. Foreign debt used only be used for highest priority project, selfliquidation project and must applied on well appraised. These projects will enhance the economic development in these countries.

\subsection{Future recommendation:}

Based on our knowledge we look forward for future research. It is recommended that we can increase the independent variables to better view to find out the foreign capital and cash inflows will positively and negatively impact GDP. We can use more test to find out more insight result of the study. We can study the impact of FDI, FPI, FR, FD and FI on GDP on whole Asian countries rather than South Asia. We can also increase the number of years in order to find out better results. We can also do this study on the highest economy growing cities of South Asia.

\section{References}

Adegbite, E. O., Ayadi, F. S., \& Felix Ayadi, O. (2008).The impact of Nigeria's external debt on economic development. International Journal of Emerging Markets, 3(3), 285-301.

Adenutsi, D. E. (2011).Financial development, international migrant remittances and endogenous growth in Ghana. Studies in Economics and Finance, 28(1), 6889.

Ajide, K. B., Raheem, I. D., \& Adeniyi, O. (2015).Output growth volatility, remittances and institutions. International Journal of Development Issues, 14(3), 190-203.

Albulescu, C. T. (2015). Do Foreign Direct and Portfolio Investments Affect Longterm Economic Growth in Central and Eastern Europe?. Procedia Economics and Finance, 23, 507-512.

Alexiou, C., Nellis, J., \& Papageorgiadis, N. (2016).The effect of patent enforcement strength and FDI on economic growth. Multinational Business Review, 24(4). 
Almfraji, M. A., \& Almsafir, M. K. (2014). Foreign direct investment and economic growth literature review from 1994 to 2012. Procedia-Social and Behavioral Sciences, 12(9), 206-213.

Craigwell, R., Jackman, M., \& Moore, W. (2010).Economic volatility and remittances. International Journal of Development Issues, 9(1), 25-42.

Freckleton, M., Wright, A., \& Craigwell, R. (2012).Economic growth, foreign direct investment and corruption in developed and developing countries. Journal of economic studies, 39(6), 639-652.

Herzer, D. (2010). Outward FDI and economic growth. Journal of Economic Studies, 37(5), 476- 494.

Iqbal Chaudhry, N., Mehmood, A., \& Saqib Mehmood, M. (2013). Empirical relationship between foreign direct investment and economic growth: An ARDL co-integration approach for China. China Finance Review International, 3(1), 26-41.

Jackman, M., Craigwell, R., \& Moore, W. (2009). Economic volatility and remittances: evidence from SIDS. Journal of Economic Studies, 36(2), 135146.

Korkmaz, S. U. N. A. (2015). The relationship between external debt and economic growth in Turkey. In Proceedings of the Second European Academic Research Conference on Global Business, Economics, Finance and Banking (EAR15 Swiss Conference) ISBN (pp. 978-1).

Kratou, H., \& Gazdar, K. (2016).Addressing the effect of workers' remittance on economic growth: evidence from MENA countries. International Journal of Social Economics, 43(1), 51-70.

Metwally, M. M. (2004). Impact of EU FDI on economic growth in Middle Eastern countries. European Business Review, 16(4), 381-389.

Mucuk, M., \& Demirsel, M. T. (2014, October). The Relationship Between Foreign Portfolio Investments And Economic Growth: The Case Of Turkey. In Proceedings of International Academic Conferences (No. 0702082). International Institute of Social and Economic Sciences.

Muhammad Adnan Hye, Q. (2012). Exports, imports and economic growth in China: an ARDL analysis. Journal of Chinese Economic and Foreign Trade Studies, $5(1), 42-55$.

Noman, A., Rahman, M. N., \& Naka, A. (2015).Portfolio investment outflow and the complementary role of direct investment. Journal of Financial Economic Policy, 7(3), 190-206. 
Pattillo, C., Poirson, H., \& Ricci, L. A. (2011).External debt and growth. Review of Economics and Institutions, 2(3), 30.

Rehman, N. U. (2016). FDI and economic growth: empirical evidence from Pakistan. Journal of Economic and Administrative Sciences, 32(1), 63-76.

Siddiqui, A. H., \& Iqbal, J. (2005). Impact of trade openness on output growth for Pakistan:An empirical investigation. Marketforces, 1(1).

Snyder, S., \&Chern, W. S. (2008). The impact of remittance income on rural households in China. China Agricultural Economic Review, 1(1), 38-57.

Srinivasan, P., Kalaivani, M., \& Ibrahim, P. (2011).An empirical investigation of foreign direct investment and economic growth in SAARC nations. Journal of Asia Business Studies, 5(2), 232-248.

Tahir, M., Khan, I., \& Shah, A. M. (2015). Foreign Remittances, Foreign Direct Investment, Foreign Imports and Economic Growth in Pakistan: A Time Series Analysis. Arab Economic and Business Journal, 10(2), 82-89.

Thankgod, O. (2014). Foreign Portfolio Investment and Economic Growth in Nigeria (1986- 2011). International Journal of Business and Social Science, 5(11).

Truett, L. J., \&Truett, D. B. (2000).The demand for imports and economic reform in Spain. Journal of Economic Studies, 27(3), 182-199.

Waqas, Y., Hashmi, S. H., \&Nazir, M. I. (2015). Macroeconomic factors and foreign portfolio investment volatility: A case of South Asian countries. Future Business Journal, 1(1), 65-74. 